\title{
Spatial development of Orthodox temple construction in Petrograd and its environs by 1917
}

\author{
Sergey Sementsov ${ }^{1, *}$ \\ ${ }^{1}$ Saint Petersburg State University of Architecture and Civil Engineering, 190005, St. Petersburg, \\ Russia
}

\begin{abstract}
The present paper discusses the results of comprehensive historical-and-archive, cartographic, bibliographic and morphological study on the development stage of Orthodox temple construction in Saint Petersburg and surrounding areas at the beginning of 1917. The integral spatial area of citizens' seasonal life was identified, within the boundaries of which the common trend of Orthodox temple placing was formed. This area included Saint Petersburg, its suburban police districts, the nearest territories, called uyezds, and the following towns under royal administration: Gatchina, Krasnoye Selo, Pavlovsk, Petergof, Oranienbaum, Strelna, Tsarskoye Selo. This integral metropolitan functional area had in total 987 cathedrals, churches, chapels and kiots; particularly in Saint Petersburg there were 676 temples, which meant that approximately each twelve developed land plots had one temple. Such an extraordinary territorial density of placing temples formed a special multilayer system of visual and skyline composition of town planning, which completely differs from a modern one that appeared after mass destructions of $1920-1960$.
\end{abstract}

\section{Introduction}

Over the past 100 years, temple architecture in Russia and particularly in Saint Petersburg was almost totally forbidden by the atheistic government. The total number of Orthodox monasteries and churches in St. Petersburg and its environs that were functioning until 1917 and were demolished after, is still unknown, as well as unknown the features of their spatial positions in the city and suburbs. This fact obstructs the evaluation of their real historical semantic-and-symbolic and city-forming role. The present paper discusses the state of Orthodox church construction in St. Petersburg before all those tsunamic destructions that fundamentally affected the general urban matrix of the city and its environs, since churches of all faiths have always been the most important symbolic and semantic centers, as well as the most important vertical dominants and centers of accumulation of visual interactions. After the 1917-1960 (the period of mass destruction of temples), Saint Petersburg and its environs started to be conceived in terms of the new

\footnotetext{
* Corresponding author: s.sementsov@mail.ru
} 
spatial composition, which did not involve the disappeared system of temples. The new spatial tradition, which was developed after the destructive years and then was accepted by the society, represented historical Leningrad (St. Petersburg until 1914, Petrograd in 19141924) as an absolutely flat city with rarely placed vertical dominants in the shape of temples. Historical building development of those years implied the one cornice level and had a consolidated and uniform horizontal outline that was spread around dozens of square kilometers. The new spatial paradigm of the city became one of the foundations of a modern understanding of the historical part of Saint Petersburg [1].

But is it actually so? In the early 1990s, the society started addressing to the architecture of temples: there have been a lot of attempts to build new and restore previously destroyed churches since $90 \mathrm{~s}$, people have returned to the studies on spatial features of temple placing. Among the research works on the history of Orthodox temple construction in St. Petersburg, ones written by the following modern researchers are especially worth noting, since they have already become classic: V.V. Antonova, A.V. Bertasha, G.V. Dluzhnevsky, E.V. Isakova, A.V. Kobaka, T.A. Slavina, M.V. Shkarovsky, S.S. Schultz Jr. and others [2; $3 ; 4 ; 5 ; 6 ; 7]$. However, the pre-revolutionary (written before 1917) publications of E.A. Bruggen, L.I. Denisova, N.M. Evreinova, N.M. Kutepova, N.A. Tikhomirova G.A. Tsitovich and other authors were even more ambitious $[8 ; 9 ; 10 ; 11 ; 12]$.

Parallel study of both archival and published sources of 19th -20 th centuries allowed quite fairly identifying the total number of Orthodox temples that functioned in St. Petersburg and its environs until 1917. Moreover, it became possible to re-evaluate features of historical spatial composition of urban and suburban landscapes taking into account the system of Orthodox churches located there and leaving non-Orthodox architecture out of the question.

\section{Materials and Methods}

The present research and the article resting on it are based on the author's results of using complex historical-and-archival, cartographic and morphological methods for investigating all currently known temples in Saint Petersburg and its environs. In order to solve the problem set in the work, the author had to answer several questions: A) what territories of the city and its environs should be considered an integral territory of summer and winter residence for the population, taking into account the traditional seasonal features of the metropolitan life in Saint Petersburg; B) how many and what kind of Orthodox temples were there in this integral territory (Saint Petersburg and its environs); C) how was the spatial system of orthodox temple architecture formed in these territories; D) to what extent was this system destroyed after 1917 and what parts of it did survive to this day?

\section{Results and Discussion}

\subsection{The area of placing Orthodox temple architecture in Saint Petersburg and its environs}

Pecularities of urban life in Petrograd (until 1914 - in Saint Petersburg), that started indurating in the beginning of the 18th century during the reign of Peter the Great, formed the unity of the city and its environs. Civilian population rigorously followed the seasonal lifestyle: in winter, from October to May, everyone, including the Emperor and representatives of the aristocracy, lived in winter apartments in Saint Petersburg, while in a summer season from May to October they moved to their countryside houses, preserving the same image and standard of living throughout a whole year. For both the aristocrats and 
the middle class, this standard of living included not only a well-developed transport system between the city and the areas of summer houses, but also shops, theaters, covered stadiums, urban amenities - roads furnishing, sidewalks, street lighting, telegraphs and telephones, etc. These seasonal migration of the royal household, noblemen, intelligentsia, magnates and merchants proceeded along with migration of Russian Imperial Army subunits, mainly life-guard and the best army regiments that had barrack areas near both city and suburban royal palace complexes. In summer those regiments were sent to summer camps for training maneuvers (for example, to such villages as Krasnoye Selo, Ust-Izhora or Sapyornoye). Large summer villages, also called "garden cities", had already formed nearby St. Petersburg by the beginning of the 20th century [13]. In each of these areas, numerous temples were erected in accordance with the lifestyle described.

In St. Petersburg, as well as in other Russian cities, they implemented a group type of placing temples that were interconnected with special bonds. For instance, cathedrals were usually surrounded by churches and chapels attributed to those cathedrals; many parish churches were accompanied by chapels. The most famous examples are the following: Alexander Nevsky Lavra that included cenobium, Theological Academy, seminary, school, compound on Vasilyevsky Island and Seraphim and Anthony skete in Luzhsky uyezd of Saint Petersburg Governorate (totally 32 temples); Voskresensky Novodevichy Convent that included a monastery school, subsidiary Vokhonovsky and Pyatogorsky Convents, churches at Kikerino railway station and in the city of Gatchina (21 temples); Coastal Monastery of Saint Sergius (13 temples); John the Apostle Convent (5 temples). In the middle of the 19th century people started reviving the tradition of placing monastery and diocese compounds in St. Petersburg and its suburbs that had referred to the years of Peter the Great reign, so in 1917 there were 53 of such monastery compounds with 90 churches and chapels.

The identification of this unified seasonal approach to urban lifestyle that really existed until 1917 required to clarify the territorial area under the study and consider it as a unity of the territory of St. Petersburg and its environs spreading down to satellite towns under royal administration, with taking into account of the integrity of their unique spatial organism.

The territorial organization (administrative structure) of Saint Petersburg and its environs was significantly different from the modern one. In those days, the rather complicated management system was valid there. The following administrative structure existed officially within the city borders: Saint Petersburg - police sections - police districts. Within the boundaries of the governorate: Saint Petersburg governorate - uyezds sectors (or volosts). Since the 1870s the total area of Petrograd (formerly, until August 1914, Saint Petersburg), within its administrative-territorial borders including the huge water area of the Gulf of Finland, 12 city administrative and police sections (Admiralteyskaya, Aleksandro-Nevskaya, Vasilyevskaya, Vyborgskaya, Kazanskaya, Kolomenskaya, Liteinaya, Moskovskaya, Narvskaya, Rozhdestvenskaya, Petrogradskaya, Spasskaya) divided into 38 administrative and police districts, amounted to 90344.89 square kilometers (79 385 square versts), which included the 105.4 square kilometers of the built-up part of the territory of approximately separated and habitable 12,500 land plots [14]. Nearly 2,300,000 people lived in these territories by the beginning of 1917 .

In 1871, a new system of suburban sections was introduced in Saint Petersburg's outskirts, which formerly were the parts of governorate's uyezds and surrounded the city bordering its verges. This system implied the introduction of city police management and regulations on life activities in accordance with the Governor of Saint Petersburg [15]. By the 1910s, this territory was divided into 8 suburban sections: Aleksandrovsky, Lesnoy, Novoderevensky, Okhtenskiy, Peterhof, Polyustrovsky (Palustrovsky) and Shlisselburgsky [16]. They became the transitional units from the capital to the governorate. Meanwhile, four administrative police uyezds of the St. Petersburg governorate were still functioning 
outside those sections' borders: Saint Petersburg, Shlisselburg, Peterhof, Tsarskoye Selo. On their territory the cities of the Imperial Palace Administration: Krasnoye Selo, Tsarskoye Selo and Pavlovsk, Gatchina, Peterhof, Oranienbaum and cities and settlements under different administrations: Pulkovo, Ust-Izhora, Kolpino, etc.

Thus, the entire territory considered in the paper contains not only Petrograd (until August 1914 Saint Petersburg), the surrounding ring of suburban sections (45 settlements) and the famous cities under the Imperial Palace Administration with associated settlements (20 settlements), but also includes a part of the Saint Petersburg governorate (5 settlements). The city itself and its closest environs comprised a single organism that was harmoniously developing over the decades and formed a majestic integral spatial-andlandscape core. Therefore, it is hardly possible to divide this organism into separate fragments: the city, each of the suburbs and territories of the outskirts.

\subsection{The scale and quantitative description of Orthodox temple architecture in Saint Petersburg and its environs.}

\subsubsection{Features of Orthodox temple architecture in Saint Petersburg}

In the beginning of the 20th century, Orthodox temples of various space-planning, compositional and style solutions erected according to designs of hundreds of architects, were functioning in the territories under consideration. Within the research, 987 temples were detected: 31 cathedrals, 622 churches, 334 chapels and kiots: it is almost 1000 Orthodox temples, which are different in grades, sizes, architectural and style features, etc. However, it is clear that there were even more Orthodox churches in the territories under consideration until 1917. Under a more careful study of archives, other temples that have not been revealed yet may be discovered (and they certainly will), moving beyond the magical number of 1000 .

\subsubsection{Temple architecture in various aspects of Saint Petersburg life}

During the research, the whole variety of Orthodox temples was divided into 2 large groups: the system of temples belonging to the civil administration and temples of the naval administration.

Civil temples (811 units) comprise the largest and most impressive group, while being divided into: monasteries, monastery compounds (162 temples); cathedrals, churches and chapels at those cathedrals (43 temples); parish churches and chapels (152 temples); churches in state institutions ( 34 temples); churches in palaces and mansions (50 temples); churches and chapels in higher, secondary and primary educational institutions (83 temples); churches and chapels in hospitals, charitable, religious-and-educational institutions and religious-and-ethic institutions (210 temples); churches and chapels at industrial enterprises and in working settlements (17 temples); churches and chapels at prisons (11 temples); churches and chapels in cemeteries (49 temples).

Military temples (176 units) are divided into 2 groups: cathedral complexes, churches and chapels at military subunits (34 temples); churches and chapels attached to military institutions, divisions, educational and medical institutions, military-and-industrial facilities, military prisons (142 temples). At the same time, almost each military temple of those times was a military museum. Each military temple at the same time was both a temple and a museum of a regiment or a subunit, a part of which it was, even if it was the entire Navy (like Saint Nickolas Naval Cathedrals St. Petersburg and in Kronstadt). Those temples exhibited military relics, trophies, awards, uniforms of chefs, generals and subunit 
officers on facades and interior walls. There were also memorials in honor and commemoration of heroic deeds and deaths of generals, officers, soldiers and sailors, with memorial tablets installed around a temple perimeter and listing heroes' names (for instance, the Church of the Savior on Waters).

\subsection{Peculiarities of formation of the spatial system of the Orthodox temple architecture in Saint Petersburg and its environs}

The image of a historical city is traditionally perceived within the paradigm of logic formulated in general terms by K. Lynch and in terma of Saint Petersburg by A.V. Stepanov $[17 ; 18]$.

The present studies showed a unique picture of the development of Orthodox temple architecture in Saint Petersburg and its environs. There are 676 temples in Saint Petersburg: almost every 12th land plot of the former Russian capital had a temple: cathedral, church or chapel (freestanding or integrated in a house). Other 303 temples were built on territories within a radius of $50 \mathrm{~km}$ from Saint Petersburg, and 8 more temples interconnected with the previous group - in the governorate. Such a scope of temple construction was unexpected. Such a high density of placing temples was unique.

During the study, 574 separately standing temples were denoted among the general list of temples: 29 cathedrals, 269 churches, 276 chapels and kiots. Totally 389 objects belong to the group of house cathedrals, churches and chapels: 2 cathedrals (naval cathedral in the name of Saint Spyridon in the Admiralty building and Cathedral in the name of The Vernicle in the Winter Palace, "Court Cathedral"), 345 churches, 42 chapels and kiots. At the same time, 24 temples cannot be attributed to any of these categories.

\section{Temples of Saint Petersburg as the main "creators" of the historical landscape and skyline of the capital city.}

General theoretical understanding of the significance of vertical dominants in spatial systems of historical cities has been comprehensively and repeatedly considered by both Russian and foreign experts $[19 ; 20 ; 21]$. When studying the placement of temples in St. Petersburg's urban area and in suburban landscapes, the following feature can be noticed: all temples, from the largest cathedrals to the smallest chapels, were placed on the main compositional axes and in all view corridors, on public open grounds, as they were the key compositional, stylistic and symbolic-and-semantic accents of town-planning.

Their role in the development of a pre-revolutionary urban matrix of the capital and the entire suburban area was not less crucial. When studying the history of Orthodox temple building in Saint Petersburg, it is absolutely impossible to divide temples into detached and house ones. Moreover, all the house churches were located in the upper floors of buildings, they had crosses, chapels, belfries that stood out of roofs and were visible from considerable distances, which made their outline look like detached buildings. According to the research works of O.N. Zakharov and S.V. Krylova (Kurakina) [22; 23] on specifying the height and outlines of Saint Petersburg temples, the following classes of temples can be distinguished in the spatial system of temples of the city and its environs (in terms of their both absolute height and height in relation to surrounding buildings) [24]:

1 st class. Dominants of governorate importance. They are 100 meters high or more, which 7-10 times exceeds the height of surrounding buildings in the years when a temple was erected. There are only a few such dominant temples: Saints Peter and Paul Cathedral (with a height of the steeple of $122 \mathrm{~m}$ ); Resurrection Cathedral of the Smolny Convent (with a height of the central cupola of $98 \mathrm{~m}$ ) and an uncompleted steeple (with a design height of $144 \mathrm{~m}$ ); Saint Isaac's Cathedral (with a height of a cross on the dome of $102 \mathrm{~m}$ ). 
These dominants provided visual organization (spatial perception) at distances up to $30-$ $40-50$ and more kilometers.

2nd class. Dominants of regional importance. They are from 70 to 90 meters high, 4-5 times exceeding the height of surrounding buildings in the years of erection. This class includes: Kazan Cathedral (the highest point of the dome is $72 \mathrm{~m}$ ); Admiralty building (with a $74 \mathrm{~m}$ high spire); the bell tower of St. Vladimir's Cathedral on Vladimirovskaya Square (72 m high); church of the Savior on Blood (81 m high); Kronstadt Naval Cathedral (71 $\mathrm{m}$ high). These dominants provided visual organization (spatial perception) at distances up to $10-20 \mathrm{~km}$.

3rd class. Dominants of city importance. Stand-alone churches with cupola's and spire's height of 50-60 m. They were erected both in the city and in the vast suburban territories. Among them there are: the church of Simeon and Anna (with a steeple height of $51 \mathrm{~m}$ ); St. Nicholas Naval Cathedral in St. Petersburg (48 m high) and a stand-alone bell tower of 57 $\mathrm{m}$ high; Holy Trinity Cathedral of the Alexander Nevsky Lavra (62 m high), etc. In the years of erection, their height 3-4 times exceeded the height of surrounding buildings during construction. Such altitude characteristics of buildings provided a visual organization of spaces within a radius of $6-10 \mathrm{~km}$.

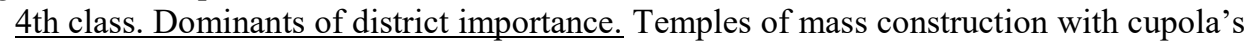
and spire's height of $40-50 \mathrm{~m}$. The designed and constructed height of this type of objects 2.5-3 times exceeded the average height of the ordinary (background) surrounding buildings, providing the visual organization of space within a radius of $4-7 \mathrm{~km}$.

5th grade. Dominants of estate importance. It is also one of the most common options of a historical high-rise development with buildings of 25-40 m high. However, in the $1820 \mathrm{~s}-$ $1910 \mathrm{~s}$, when background buildings of up to $24.5 \mathrm{~m}$ high were massively erected, such dominants started to be built with a height of up to $40 \mathrm{~m}$, which could ensure their rising above background buildings approximately by $1.5-2$ times. These dominants were also well perceived in the visual field, within radius of up to $2-5 \mathrm{~km}$.

6th class. Local dominants. Such dominants can be divided into 2 groups: for the upper (skyline) zone and for the basement zone. The upper zone of buildings involved dominants in the form of turrets, spires, domes (with a total height of 20-22 $\mathrm{m}$ above the ground by the end of the 18th century, and of 30-35 m by the end of the 19th century) that exceeded the height of a cornice of a historical building by 2-5-8 meters, which ensured that such dominants are only 1.1-1.2 times higher than background buildings. Such sacral temple tops were widely spread in areas of urban and suburban development, providing a visual arrangement of space, yet within a radius of 0.5-1-2 km. The same class has a large group of various chapels (each of 5-10 m high), which from perspective of an average human height made special accents and created the symbolic urban environment in zones of human perception.

There is one more feature of Saint Petersburg that is worth noting. People got used to the fact that nowadays historical buildings of the city form a unique straightly horizontal skyline penetrated by rarely placed vertical dominants in the shape of temples. However, this was not so before 1917. Firstly, the palace and ribbon building development of St. Petersburg until 1917 was various-story (varying from 2 to 5 floors, according to Imperial Edict: no higher than the cornice line of the Imperial Winter Palace, i.e. no higher than 23.5 $\mathrm{m})$, many land plots still retained 1-2-story wooden buildings. Only after the planned erection of additional stories (accomplished according to a single program!) for hundreds of buildings in the 1930s-1950s, the city center received its harmonious uniform cornice line (corresponding to the level of the Winter Palace's cornice line), which today delights so many people. Secondly, before the $1920 \mathrm{~s}$, as it has been already seen, not dozens (as it is now), but thousand temples were integrated into the historical structure of the city and its suburbs. Thirdly, the urban matrix (visual-compositional and symbolic) had a multi-level 
nature, it was created through the multi-altitude system of temples. The lower level that is the closest to the human scale was created through semantic design and outlines of chapels and kiots. The next one is the level of completion of building walls with crosses, cupolas, belfries of house churches, bell towers. The higher level is the one of cupolas and bell towers of stand-alone churches (parish, suburban, industrial, etc.). The next is the level of cathedrals and churches of the 2nd temple class. Finally, the outlines of the major cathedrals (Smolny, Saint Isaac's, Kronstadt Naval Cathedrals) dominated rising above all other buildings. Such a man-made multilayer silhouette of urban and suburban space, "lace" in terms of the morphology of architectural means, was harmonious for a person with his or her psychologically and physiologically substantiated patterns of perception of both the integral space and individual spatial images.

\subsection{The extent of destruction of the system of Orthodox temple architecture in Saint Petersburg and its environs. The degree of preservation of elements belonging to this pre-revolutionary system}

The colossal amount of stand-alone and house temples was gradually destroyed since the beginning of the 1920s. temples disappeared from urban and suburban pattern, after which a very simplified, smooth urban matrix was created without lacelike line of vertical dominants, but with a flat-rise background building development. Disappearance of such a unique layer of architectural objects has become an irreplaceable loss for the entire spatial and symbolic composition of Saint Petersburg and its environs. All those current attempts to introduce modern objects with their poor geometric volumes into historical urban matrix, into historically formed landscapes will never make up for the historical complexity of the temple system that was eliminated under the strokes of history.

\section{Discussion}

The proceedings of the present paper are the first, among historical and urban studies dedicated to the development of Saint Petersburg and its environs (suburban area), showing the scale and unique density of Orthodox temple architecture, which was creating a unified spatial system of symbolic and visual (vertical) dominants from the 19th till the beginning of the 20 th century.

\section{Conclusions}

As the result of the study, a total number of various Orthodox temples in Saint Petersburg and its suburbs was detected for the first time: the amount was almost 1000 (987) temples. The integral area of placing all the groups of temples was identified for the first time, which involved the city of Saint Petersburg, suburban administrative sections adjacent to its administrative borders and the towns under royal administration. Moreover, 6 classes of temples as vertical dominants were detached, that form a spatial-and-visual field in Saint Petersburg and its environs (from several major temples of governorate importance to mass temples belonging to the local class). The extent of destruction and loss in Orthodox temple architecture and in the entire spatial system of vertical dominants of Saint Petersburg and its environs was discussed as well. 


\section{Recommendations}

The article may be of interest to historians of architecture and urban planning, experts in the protection, conservation and restoration of historical and cultural heritage, town planners, architects, urbanists, designers who are concerned with the development of modern cities and metropolitan areas, as well as the preservation of historical cities and landscapes.

I want to express my gratitude to the colleagues who have patiently and passionately treated the longterm and laborious studies on this topic, namely to Father Alexander, A.E. Belonozhkin, D.A. Borunov, S.V. Krylova (Kurakina), M.A. Mamoshin, N.A. Akulova, E.R. Wozniak, K.A. Romanchuk.

\section{References}

1. Decree of the Government of St. Petersburg of November 1, 2005 No. 1681 "On the St. Petersburg Strategy for the Preservation of Cultural Heritage".

2. V.V. Antonov, A.V. Kobak, Svyatyni Sankt-Peterburga. Istoriko-tserkovnaya entsiklopediya $v$ trekh tomakh (1996).

3. A.V. Bertash, Khramy Peterburga: Spravochnik-putevoditel (SPb., Inform.-izd. "LIK", 1992)

4. G. Dluzhnevskaya, Utrachennyye khramy Peterburga (SPb., Litera, 2003)

5. Ye.V. Isakova, M.V. Shkarovskiy, Khramy Kronshtadta (SPb., Paritet, 2004)

6. T.A. Slavina, Konstantin Ton (Lenizdat, 1982)

7. S.S. Shul'ts-mladshiy, Khramy Sankt-Peterburga. Istoriya i sovremennost' (SPb., Izd. «GLAGOL"», 1994)

8. N.M. Yevreinov, E.A. Bryuggen, Lavry, monastyri $i$ khramy na Sv. Rusi. S.Peterburgskaya yeparkhiya (SPb., Tip. Uchi-lishcha glukhonemykh" Vedomstva Uchrezhdeniy Imperatritsy Marii, 1908)

9. L.I. Denisov, Pravoslavnyye monastyri Rossiyskoy Imperii (Moscow, Izd. "A.D. Stupin", 1908)

10. N.M. Kutepov, Pamyatnaya knizhka po S.-Peterburgskoy yeparkhii (SPb., Tip. Otdel'nago Korpusa Pogranichnoy strazhi, 1899)

11. N.A. Tikhomirov, Putevoditel' po tserkvam g. S.-Peterburga i blizhayshikh yego okrestnostey (SPb., Izd. knizhn. magazina "Vera i Znaniye", 1906)

12. G.A. Tsitovich, Khramy armii i flota (sostoyashchie v" Vedomstve Protopre-svitera Voyennago i Morskago dukhovenstva) (Pyatigorsk, Tipo-litografiya A.P. Nagorova, 1913).

13. S.V. Sementsov, Vestnik grazhdanskikh inzhenerov 5(70), 26-49 (SPb., SPbGASU, 2018)

14. P. Semenov, V. Zverinskago, R. Malka, L. Maykova, N. Filippova, Geograficheskostatisticheskiy slovar' Rossiyskoy Imperii. sosta-vil" po porucheniyu imperatorskago russkago geograficheskago obshchestva (Sanktpeterburg, Tip. V. Bezobrazova i Komp., Izhdiveniyem" A.N. Turubayeva, 1873)

15. № 49.718. 1871 g. Iyunya 8. Vysochayshe utverzhdennoye mneniye Gosudarstvennago Soveta «Ob" ustroystve politsii v" prigorodnykh" k" S.-Peterburgu mestnostyakh"» (SPb., 1874) 
16. A.P. Shashkovskiy, Ves' Petrograd" na 1916 god. Adresnaya i spravochnaya kniga Petrograda (A.S. Suvorina "NOVOYe VREMYA", 1916)

17. K. Linch, Obraz goroda (Moscow, Stroyizdat, 1982)

18. A.V. Stepanov, Fenomenologiya arkhitektury Leningrada (SPb., "Arka", 2016)

19. Ye.L. Belyayeva, Arkhitekturno-prostranstvennaya sreda goroda kak ob"yekt zritel'nogo vospriyatiya (Moscow, Stroyizdat, 1977)

20. A.YU. Nazarova, Vestnik Tomskogo GASU 21(3), 77-85 (2019).

21. S. Bostanci, M. Oral, ICONARP. International Journal of Architecture and Planning, 53-55 (2017)

22. O.N. Zakharov, Arkhitekturnyye panoramy nevskikh beregov (Leningrad, Stroyizdat, 1984)

23. S.V. Krylova, Moskovskiy vestnik inzhenerov 3(28), 15-22 (2013)

24. S. Sementsov, N. Akulova, S. Kurakina, E3S Web of Conferences 33, 01008 (2018) 